\title{
Manajemen Pengaturan Persentase Pemberian Pakan pada Jadwal Waktu Pemberian Makan terhadap Tingkah Laku Makan Ayam Petelur Jantan
}

\author{
T.D. Nova ${ }^{1}$, Y. Heryandi ${ }^{1}$, \& P. Ilham ${ }^{2}$ \\ ${ }^{1}$ Bagian Tehnologi Produksi Ternak, Fakultas Peternakan Universitas Andalas \\ ${ }^{2}$ Program Studi Produksi Ternak, Fakultas Peternakan, Universitas Andalas \\ Fakultas Peternakan Kampus Limau Manis, Pauh Padang \\ Email: tnova@ansci.unand.ac.id \\ (Diterima : 25 Mei 2020; Disetujui : 21 September 2020)
}

\begin{abstract}
This study aims to determine the timing of proper feeding of male hens and how to eat male hens to meet there daily needs. The feeding behavior parameters observed were screening observations (scores), number of strokes (times/5 minutes), feeding breaks at the time of observation (seconds), and the remaining feed in the drinking water (mg). The results of the variance analysis showed the percentage of feed amounting to the feeding time schedule had a significant effect $(P<0.05)$ on screening results, number of stakes and residual feed in the drinking water but did not significantly $(P>0.05)$ on feeding breaks. The results of the study showed that the screening score of 2.54-2.99, (noise at score skrining (2-3) the number of adlibitum pegs was 428.63 times/5 minuts and the difference in the percentage of administration was 488.24-541.50 times/5 minutes, eating breaks 207.59-235.64 seconds, and the remaining feed in the adlibitum drinking pot $8.32 \mathrm{mg}$ and the results of the difference in the percentage of giving 11.58-17.78 mg. The concluded of the research, that the percentage of the amount of feeding with the time schedule of given affects the behavior of eating male hens. Male hens given adlibitum feed showed calmer eating behavior than chickens fed at percentages and mealtimes.
\end{abstract}

Keywords: Adlibitum, feed, feeding behavior, male hens, percentage of feed

\section{PENDAHULUAN}

Ayam petelur jantan merupakan produksi ikutan dari industri penetasan ayam petelur komersial, karena yang menjadi tujuan utama dari penetasan ayam petelur komersial adalah yang betina. Anak ayam betina (DOC) yang dihasilkan akan dipelihara dan dibesarkan untuk dipersiapkan menjadi penghasil telur, sedangkan ayam jantan nantinya akan menjadi limbah hasil produksi dan umumnya dibuang, dibakar, dibunuh atau dimanfaatkan untuk tujuan tertentu. Bahkan bagi perusahaan penetasan ayam yang skala besar, anak ayam petelur jantan tidak ada nilai ekonomisnya.

Pada beberapa negara, seperti juga Indonesia ayam petelur jantan ini masih dimanfaatkan sebagai penghasil daging dalam rangka mengejar pemenuhan konsumsi protein hewani di Indonesia yang masih rendah yaitu 5,6 g/kapita/hari dari target $15 \mathrm{~g} /$ kapita/ hari (Widya Karya Nasional Pangan dan Gizi, 2012). Ayam petelur jantan diharapkan menjadi alternatif sumber mata pencaharian baru bagi masyarakat luas pada sektor peternakan. Ayam petelur jantan dapat dijadikan sebagai pengganti peran ayam kampung untuk memenuhi permintaan masyarakat dan memenuhi kebutuhan protein keluarga dan dapat disajikan di restoran dan rumah makan.
Sebagai substitusi pemenuhan sumber protein dari ayam broiler adalah itik, puyuh dan daging ayam yang berasal dari petelur afkir. Ketiga alternatif tersebut tidak menjadikan daging sebagai tujuan utamanya, melainkan telur sedangkan daging akan dihasilkan diakhir masa produksinya apabila tidak produktif lagi. Pada ayam petelur jantan, dimana daging merupakan produksi utamanya. Menurut Bell dan Weaver (2002) secara genetik rasio jantan betina yang dihasilkan dari proses penetasan adalah 50:50 persen, artinya terdapat 50 persen DOC ayam jantan setiap penetasan yang siap untuk dijadikan sebagai penghasil daging.

Potensiayamyangbiasa digunakansebagai ternak penghasil telur adalah ayam betina, sedangkan ayam yang digunakan sebagai penghasil daging adalah ayam jantan dengan demikian kemungkinan anak ayam petelur jantan sebagai penghasil daging cukup besar. Menurut kebiasaan masyarakat yang lebih suka mengonsumsi daging ayam kampung yang lebih rendah lemak dibandingkan broiler, terkendala dengan harga ayam kampung yang cukup mahal dan sulit untuk didapatkan. Maka disinilah ayam petelur jantan dapat berperan.

Ayam petelur jantan saat ini dijadikan produk substitusi untuk ayam kampung karena tekstur dan rasa yang menyerupai ayam kampung. Ayam ini memiliki keunggulan 
tahan terhadap penyakit, secara relatif harga jual yang lebih tinggi dari ayam broiler, dan bobot panen dapat diatur dengan pengaturan protein pakan untuk menyesuaikan dengan keadaan pasar. Ayam petelur jantan umumnya dipasok ke rumah makan atau restoran.

Tujuan pemeliharaan ayam petelur jantan sama dengan ayam broiler sebagai penghasil daging namun pertumbuhan ayam petelur jantan relatif mengikuti pola pertumbuhan ayam kampung sehingga dalam manajemen dan penyediaan ransum perlu penyesuaian (Wasiudin, 2011). Manajemen pemberian pakan ayam harus memperhitungkan waktu yang tepat sehingga konsumsi dapat digunakan secara efisien. Jumlah konsumsi ransum dipengaruhi oleh kandungan energi ransum, jumlah pemberian dan temperatur lingkungan. Seperti layaknya broiler atau unggas secara umum memenuhi kebutuhan energi pada siang hari yang relatif panas, ayam mengurangi konsumsi ransum untuk mengatasi panas tubuh dan mempengaruhi tubuh.

Pada suhu lingkungan yang tinggi aktivitas tubuh berkurang, konsumsi pakan berkurang dan konsumsi air minum meningkat. Jika ayam berada di luar suhu nyamannya maka konsumsi pakan akan berkurang dan ayam tidak bisa mencapai pertumbuhan optimumnya. Suhu nyaman untuk mencapai pertumbuhan optimum ayam pedaging berkisar $18-22^{\circ} \mathrm{C}$ dan $21-29^{\circ} \mathrm{C}$ (Charles, 2002). Pemberian pakan pada pagi hari dan malam hari dimana suhunya yang relatif lebih rendah jika dibandingkan pada siang hari maka ayam akan mengonsumsi pakan yang lebih optimal.

Tingkah laku (perilaku) hewan merupakan reaksi atau ekspresi yang timbul atas rangsangan baik dari luar maupun dalam tubuh yang diterima oleh hewan sehingga ayam akan mengekspresikannya melalui tingkah laku. Sesuai dengan pernyataan Jahja (2000) bahwa suhu lingkungan berbeda mempengaruhi aktivitas tingkah laku ayam seperti makan, minum, panting, lokomosi, dan istirahat. Faktor lain yang juga penting untuk diperhatikan yaitu bagaimana ketepatan waktu pemberian pakan. Ayam yang makan diwaktu yang tidak tepat akan membuat konsumsi pakannya menurun, sedangkan jika ayam yang mendapatkan pemberian pakan yang sesuai dengan kondisi lingkungannya akan mengonsumsi pakan dengan lebih optimal.

Oleh karena itu perlu riset untuk mengamati tingkah laku makan ayam petelur jantan dalam memenuhi kebutuhannya dan berapa kebutuhan sebenarnya ayam petelur jantan yang optimal serta kapan waktu pemberian pakan yang baik melalui riset proporsi pemberian pakan pada waktu yang berbeda sehingga diketahui proporsi makan dan waktu pemberiannya yang dapat memberikan performa optimal ayam petelur jantan pada masa pertumbuhan.

\section{MATERI DAN METODE}

Materi penelitian adalah anak ayam petelur jantan day old chick (DOC) strain Hy Line Brown yang diproduksi PT. Charoen Phokpan Jaya Farm, sebanyak 125 ekor dengan bobot badan rata-rata umur sehari $34 \mathrm{~g}$.

Ransum percobaan dalam penelitian yaitu pakan yang disusun sesuai dengan kebutuhan nutrisi ayam kampung. Pakan nantinya akan diberikan sesuai perlakuan yang dimana pada minggu pertama DOC diberikan secara adlibitum untuk penyesuaian lingkungan. Pakan akan ditimbang dan diberikan sesuai kebutuhan ayam sesuai umurnya. Pemberian air minum diberikan secara adlibitum. Bahan komposisi penyusun ransun penelitian pada Tabel 1, hasil analisa ransum Tabel 2 dan kandungan nutrisi dan energi metabolisme ransum penelitian Tabel 3 .

Tabel 1. Bahan dan komposisi bahan penyusun ransum penelitian

\begin{tabular}{lc}
\hline Bahan-bahan Penyusun Ransum & Ransum \% \\
\hline Jagung & 56 \\
Dedak & 21 \\
Tepung Ikan & 10 \\
Bungkil Kedele & 10 \\
Minyak Kelapa & 2 \\
Top Mix & 1 \\
Total & 100 \\
\hline
\end{tabular}


Tabel 2. Hasil analisis bahan penyusun ransum ayam petelur jantan

\begin{tabular}{lcccccc}
\hline Bahan Ransum & PK & LK & SK & Ca & P & ME \\
\hline Jagunga $^{\text {a }}$ & 8,28 & 2,66 & 2,99 & 0,37 & 0,90 & 3300 \\
Dedak $^{\mathrm{a}}$ & 12,9 & 4,09 & 16,15 & 0,69 & 0,26 & 1640 \\
Tepung Ikan $^{\mathrm{b}}$ & 35,81 & 1,52 & 2,80 & 5,50 & 2,88 & 3080 \\
Bungkil Kedelaic $^{\mathrm{c}}$ & 45,00 & 2,49 & 7,50 & 0,63 & 0,32 & 2240 \\
MinyakKelapa & - & 100 & & - & - & 8600 \\
Top Mix & - & & & 5,83 & 0,34 & - \\
\hline
\end{tabular}

Keterangan:

Laboratorium Tehnologi Industri Ternak Peternakan Unand 2016

Batubara (2012)

Nuraini et al. (2013).

Tabel 3. Kandungan nutrisi dan energi metabolisme ransum penelitian

\begin{tabular}{lc}
\hline Nutrisi Ransun & Ramsum \% \\
\hline Protein kasar & 15,01 \\
Lemak & 4,75 \\
Serat kasar & 6,02 \\
Kalsium & 1,02 \\
Fosfor & 0,49 \\
Energi metabolisme (Kkal) & 2896,40 \\
\hline
\end{tabular}

\section{Kandang Percobaan}

Kandang pemeliharaan yang digunakan adalah kandang box yang disekat sebanyak 25 unit kandang dengan ukuran $0,7 \mathrm{~m} \times 0,7 \mathrm{~m}$ $\times 0,8 \mathrm{~m}$. Untuk bagian atas kandang ditutup dengan dengan wareng. Setiap unit kandang berisi 5 ekor ayam petelur jantan. Setiap kandang dilengkapi satu tempat minum dan satu unit tempat pakan yang memanjang.

Peralatan yang digunakan dalam penelitian ini adalah tempat pakan (feeder), tempat air minum (waterer), lampu pijar 65 watt/boks digunakan sebagai sumber pemanas buatan, 1 buah lampu pijar 65 watt sebagai penerang, ember, timbangan digital untuk menimbang, koran, kamera digital dan kamera handphone sebagai alat dokumentasi, alat penghitung (handcounter), termometer, alas kandang, gunting, pisau, vaksin dan desinfektan.

\section{Rancangan Penelitian}

Penelitian ini dilakukan dengan metode eksperimen, menggunakan Rancangan Acak Lengkap (RAL) dengan 5 perlakuan pemberian pakan dan 5 kali ulangan. Setiap unit percobaan terdapat 5 ekor ayam. Masing-masing perlakuan dibedakan oleh persentase jumlah pemberian pakan pada jadwal pemberian makan. Perlakuan akan diterapkan pada minggu ke-2 penelitian.

Kriteria perlakuan sebagai berikut :

P0: Pemberian pakan adlibitum

P1: Pemberian pakan 30\% pagi - siang dan 70\% sore - malam.

P2: Pemberian pakan $40 \%$ pagi - siang dan $60 \%$ sore - malam.

P3: Pemberian pakan $50 \%$ pagi - siang dan $50 \%$ sore - malam.

P4: Pemberian pakan $60 \%$ pagi - siang dan $40 \%$ sore - malam.

Keterangan :

Pagi - Siang : 07.00 - 15.00 WIB

Sore - Malam : 15.05 - 23.05 WIB

Pakan diberikan adlibitum pada umur 1-7 hari. Setelah itu pada umur 8-70 hari dilakukan pemberian pakan sesuai perlakuan dengan frekuensi pemberian pakan yang sama dengan 4 kali pemberian pagi-siang dan 4 kali pemberian pada sore-malam dengan rentang waktu 8 jam pagi-siang dan 8 jam sore-malam.

Waktu pemberian pakannya yaitu pada pukul 07.00-07.10, 09.00-09.10, 11.00-11.10 dan 13.00-13.10 pada pemberian pagi-siang dan 
pada pukul 15.05-15.15, 17.05-17.15, 19.05-9.15 dan 21.05-21.15 pada pemberian sore - malam.

Model matematis dari rancangan yang digunakan dalam penelitian ini adalah sebagai berikut: $\quad Y i j=\mu+\alpha i+\varepsilon i j$

$\mathrm{Y}=$ Nilai pengamatan karena pengaruh perlakuan ke-i dan pada ulangan ke-j

$\mathrm{m}=$ Nilai tengah umum

$\alpha \mathrm{i}=$ Nilai tambah karena pengaruh perlakuan ke - i

eij $=$ Pengaruh galat dari percobaan

$\mathrm{i}=\operatorname{Perlakuan}(\mathrm{A}, \mathrm{B}, \mathrm{C}, \mathrm{dst})$

$\mathrm{j}=\operatorname{Ulangan}(1,2,3$, dst $)$

Data yang diperoleh kemudian dianalisis dengan analisis ragam jika berbeda nyata pada taraf $1 \%$ dan $5 \%$ dilanjutkan dengan uji Duncan Multiple Range Test (DMRT). Khusus untuk data skrining karena pengamatan menyeluruh pada setiap unit kandang, data dianalisis secara deskriptif.

\section{Peubah yang diamati}

Peubah yang diamati pada penelitian ini adalah skrining, jumlah patukan, jeda makan pada waktu pengamatan dan sisa pakan dalam tempat minumnya. Perhitungan masingmasing peubah penelitian adalah :

1. Skrining (skor). Skrining diamati dengan melihat tingkat kecepatan dan keterburuan ayam ketika memakan pakannya (pengamatan dilakukan secara menyeluruh terhadap semua populasi ayam dalam waktu 5 menit),

Ukurannya dapat dinilai melalui skoring :

a. Sangat tenang $(0-1)$

b. Tenang $(1-2)$

c. Ribut $(2-3)$

d. Sangat ribut $(3-4)$

Kriteria pengamatan data skrining ayam petelur jantan selama penelitian dapat dilihat pada Tabel 4.

Tabel 4. Kriteria pengamatan data skrining ayam petelur jantan selama penelitian

\begin{tabular}{llllll}
\hline No & Indikator & Sangat Tenang (1) & Tenang (2) & Ribut (3) & Sangat Ribut (4) \\
\hline 1 & Cara Makan & Sangat pelan & Pelan & Terburu-buru & Sangat terburu \\
2 & Penyebaran ayam & Berpencar & $\begin{array}{l}\text { Cukup } \\
\text { berpencar }\end{array}$ & $\begin{array}{l}\text { Agak } \\
\text { berkelompok }\end{array}$ & Berkelompok \\
3 & $\begin{array}{l}\text { Suara } \\
\text { Kibut }\end{array}$ & Sangat Ribut \\
& $\begin{array}{l}\text { Kerapatan berdiri } \\
\text { saat mematuk } \\
\text { pakan }\end{array}$ & Sangat diam & Diam & Rapat & Sangat Rapat \\
5 & Pergerakan & Sangat menyebar & Menyebar & $\begin{array}{l}\text { Tidak terlalu } \\
\text { menyebar }\end{array}$ & $\begin{array}{l}\text { Tidak menyebar/ } \\
\text { satu tempat }\end{array}$ \\
\hline
\end{tabular}

Dari hasil data yang diperoleh dikonversikan ke dalam skala angka dan dibahas secara deskriptif dengan melihat angka rataan pada masing-masing perlakuan.

2. Jumlah Patukan (kali/ 5 menit). Pengamatan yang dilakukan untuk menghitung seberapa banyak ayam mematuk pakannya selama 5 menit dari awal pakan diletakkan. Pengamatan dilakukan pada setiap waktu pemberian makan. Data yang diperoleh dianalisis dan dibahas secara deskriptif.

3. Jeda makan pada waktu pengamatan (detik). Jeda makan pada waktu pengamatan adalah memperhatikan berapa lama ayam tersebut melakukan jeda saat mengkonsumsi pakannya dalam waktu 5 menit. Pengamatan jeda makan dilakukan 30 menit setelah pengamatan makan. Data yang diperoleh dikuantitatifkan dan dianalisis untuk dibahas secara deskriptif.

4. Sisa pakan dalam tempat minum (mg). Pengamatan yang dilakukan dengan menghitung sisa pakan yang terbuang pada saat ayam mengkonsumsi pakannya. Sisa pakan dalam tempat minum diambil setiap setelah pemberian makan pagi-siang dan juga pada pemberian makan soremalam. Selanjutnya dikeringkan sampai menjadi bubuk dan berwarna kehitaman dan ditimbang. Ayam dipelihara dan diberikan perlakuan sampai umur 10 minggu. 
5. Pengamatan tingkah laku makan dilakukan pada setiap 3 hari berturut dalam satu minggu. Pencatatan data tingkah laku dilakukan secara manual dari umur 15 hari sampai umur 70 hari. Pencatatan data tingkah laku makan dilakukan secara manual dengan pengamatan sesuai dengan masingmasing perlakuan. Data tingkah laku makan dicatat dalam tabel pencatat seperti Tabel 5.

Tabel 5. Pemberian pakan ayam petelur jantan

\begin{tabular}{cc}
\hline Umur (Minggu) & Konsumsi Ransum (g/ekor/hari) \\
\hline 1 & 12,1 \\
2 & 18,7 \\
3 & 24,2 \\
4 & 30,8 \\
5 & 38,4 \\
6 & 45,0 \\
7 & 51,7 \\
8 & 56,1 \\
9 & 60,4 \\
10 & 63,8 \\
\hline
\end{tabular}

\section{Pelaksanaan Penelitian}

\section{a. Persiapan Kandang dan Perlengkapan}

Sebelum penelitian dilaksanakan, kandang dicuci dan dibilas dengan air, setelah kering dilanjutkan dengan pengapuran dinding dan lantai kandang. Setelah pengapuran dilakukan penyemprotan di dalam kandang dengan rhodalon. Peralatan makan dan minum juga dicuci dan disterilkan.

\section{b. Penempatan ayam petelur jantan dalam kandang}

Penempatan ayam pada setiap unit kandang dilakukan secara acak (random). Penempatan perlakuan proporsi pemberian pakan dalam petak kandang dilakukan secara acak seperti terlihat pada Gambar 1.

\begin{tabular}{|c|c|c|c|c|}
\hline P3U4 & P3U2 & P4U5 & P1U2 & P3U3 \\
\hline P4U1 & P4U3 & & P0U3 & P1U4 \\
\hline P1U5 & P2U4 & & P4U4 & P2U3 \\
\hline P2U5 & P1U3 & & P0U5 & P0U3 \\
\hline P0U4 & P2U1 & & P3U5 & P4U2 \\
\hline $2 \mathrm{U} 2 \mathrm{P}$ & P1U1 & & POU2 & P3U1 \\
\hline
\end{tabular}

Gambar 1. Bagan penempatan ayam petelur jantan dalam kandang

Keterangan :

U1-U5 : Ulangan; P0-P4 : Perlakuan

\section{c. Pemberian pakan}

Pakan diberikan sesuai perlakuan P0 : pemberian pakan ad-libitum. P1 : Pemberian pakan 30\% pagi-siang dan $70 \%$ sore-malam. P2: Pemberian pakan $40 \%$ pagi-siang dan $60 \%$ soremalam. P3 : Pemberian pakan 50\% pagi-siang dan 50\% sore-malam. P4 : Pemberian pakan $60 \%$ pagi-siang dan $40 \%$ sore-malam. Pada persiapan pemberian pakan semua penutup tempat pakan dipasang dan diganti dengan tempat pakan yang baru, setelah itu tutupnya dilepas untuk mendapatkan pemberian pakan yang serentak pada setiap unit kandang. Begitu seterusnya setiap pemberian pakan. Untuk pemberian pagi-siang yaitu dari pukul 07.0015.10 lalu sisa pakanya di ambil dan ditimbang lalu diganti dengan tempat pakan baru yang sudah disiapkan sebelum pemberian pakan sore-malam. Pada pemberian pakan soremalam dari pukul 15.05-23.15 tempat pakan diangkat dan diturunkan dari kandang. Setiap pemberian pakan dilakukan penimbangan dan dicatat untuk mengetahui konsumsi ransum.

\section{d. Pemberian Minum}

Pada minggu pertama diberikan air minum yang dicampur dengan gula untuk menghindari DOC dari stres. Penggantian air minum dilakukan pada pagi dan sore hari.

\section{e. Kebersihan Kandang}

Untuk menjaga kebersihan kandang dari kotoran dan sisa pakan, kandang dibersihkan setiap pagi dan sore hari. 


\section{HASIL DAN PEMBAHASAN}

\section{Pengaruh perlakuan terhadap pengamatan secara skrining}

Berdasarkan hasil pengamatan menunjukkan skor skrining ayam petelur jantan makan dengan ribut. Angka rataan skor yang terendah terlihat pada ayam yang diberikan perlakuan P0 (adlibitum) yaitu 2,54, sedangkan ayam dengan perlakuan (P1, P2, P3, dan P4) mendapatkan skor yang lebih tinggi 2,88-2,99. Hal ini disebabkan kesempatan waktu makan ayam yang diberikan makan tanpa dibatasi waktu makan malam hari tersebut lebih baik. Pakan yang tersedia setiap saat pada tempat pakan membuat ayam tidak terlalu berebut makan setiap waktu, sehingga pada saat makan tidak semua ayam mematuk pakannya di tempat makan. Hasil penelitian ini disajikan dalam Tabel 6.

Tabel 6. Rataan data skrining ayam petelur jantan pada penelitian

\begin{tabular}{lcc}
\hline \multicolumn{1}{c}{ Perlakuan } & Skor & Keterangan \\
\hline P0 (adlibitum) & 2,54 & ribut \\
P1 (30\% pagi - siang 70\% sore - malam) & 2,99 & ribut \\
P2 (40\% pagi - siang 60\% sore - malam) & 2,96 & ribut \\
P3 (50\% pagi - siang 50\% sore - malam) & 2,88 & ribut \\
P4 (60\% pagi - siang 40\% sore - malam) & 2,97 & ribut \\
\hline
\end{tabular}

Keterangan: Skoring sangat tenang $(0-1)$; tenang $(1-2)$; ribut $(2-3)$; sangat ribut $(3-4)$.

Angka skor skrining dari hasil penelitianini menunjukkan ayam yang diberikan perlakuan P1, P2, P3, dan P4 lebih ribut dibandingkan ayam yang diberikan pakan adlibitum dalam mengonsumsi pakan. Hal ini disebabkan oleh pembatasan waktu makan pada malam hari menyebabkan tembolok kosong. Sesuai dengan pernyataan Jerry (2005) bahwa perilaku makan disebabkan karena rasa lapar yaitu adanya kontraksi lambung yang kosong, sehingga ayam berkeinginan untuk mengonsumsi pakan di pagi hari dengan cepat. Hal ini dilakukan ayam untuk memenuhi kebutuhan energi yang tidak terpenuhi pada saat malam hari. Pada pemberian pakan selanjutnya ayam akan makan terburu-buru dan terjadi perebutan dalam mengonsumsi pakannya.

Persentase jumlah pemberian pakan dapat menyebabkan perubahan tingkah laku makan ayam. Pada saat mengonsumsi pakannya, ayam cenderung memilih pakan dalam bentuk pecahan terlebih dahulu, yaitu jagung. Jagung merupakan bahan ransum yang mengandung karbohidrat yang tinggi untuk memenuhi energi tubuh. Konsumsi energi ayam dengan cepat pada perlakuan P1, P2, P3 dan $\mathrm{P} 4$ belum memenuhi kebutuhan nutrisi ayam secara keseluruhan, sedangkan ayam yang diberi pakan adlibitum makan dengan tenang pada setiap waktu pemberian pakan, karena ketersediaan pakan terus menerus setiap waktu. Ayam pedaging memiliki kecenderungan akan makan lebih banyak jika ada kesempatan untuk makan seperti pada pemberian pakan adlibitum dan konsumsi pakan akan berkurang jika waktu pemberian pakan dibatasi, berkurangnya konsumsi pakan ini seiring dengan lamanya pemberian pakan (Amrullah, 2003).

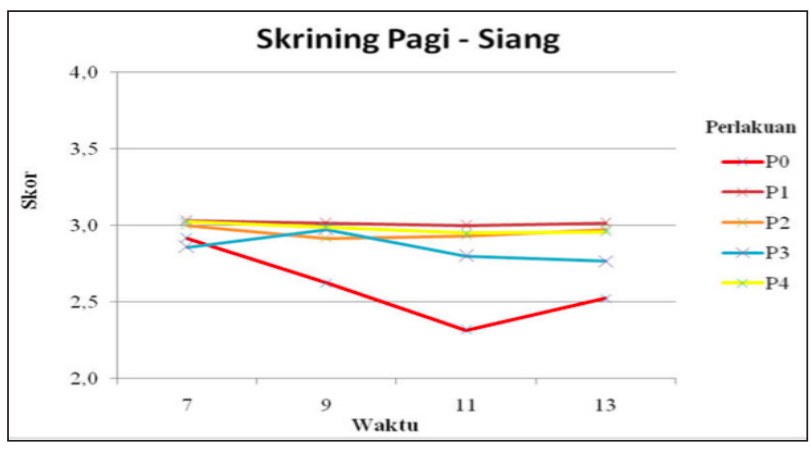

Gambar 2. Grafik skrining pada waktu pemberian makan pagi - siang

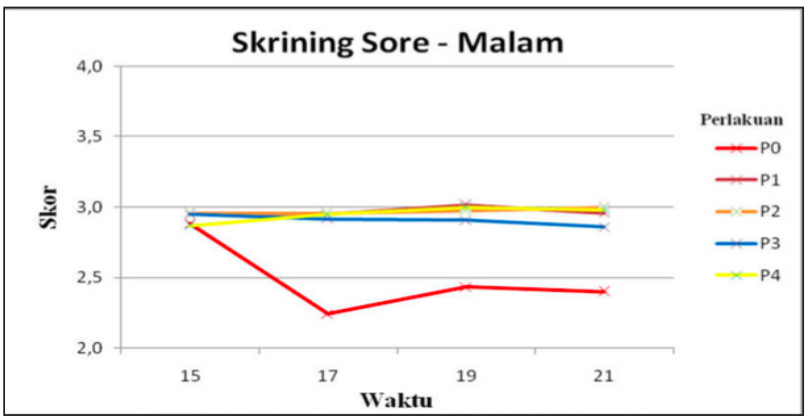

Gambar 3. Grafik skrining pada waktu pemberian makan sore - malam

Analisis berdasarkan perlakuan waktu pemberian pakan pada Tabel 7 yang digambarkan dengan grafik pada Gambar 2 
dan Gambar 3 menunjukkan skor skrining yang diperoleh pada masing-masing perlakuan pada setiap jam pemberian makan. Perlakuan P1, P2, P3, dan P4 menunjukkan skor skrining yang tidak jauh berbeda pada setiap waktu pemberian makan, karena pada setiap jam pemberian makan ayam dengan perlakuan P1, P2, P3, dan P4 selalu ribut dan terburuburu dalam mengkonsumsi pakan secara berkelompok. Sesuai dengan pernyataan De jong et al. (2003) faktor frekuensi dan lama waktu ransum disediakan selama periode pembatasan dapat menyebabkan terjadinya persaingan pada ayam dalam kelompok untuk mendapatkan pakan.

Berdasarkan perbandingan dari grafik tersebut terlihat ayam petelur jantan yang diberikan pakan dengan perbedaan persentase pagi-siang dan sore-malam tidak menunjukkan perbedaanskor. Setiapayamyangmendapatkan perlakuan yang berbeda mengonsumsi pakan dengan ribut (Tabel 6). Pada perlakuan P0 yang diberikan ketersediaan pakan selama 24 jam tidak memiliki kecenderungan untuk berebut dalam kelompok pada setiap jam pemberian. Tetapi hanya terlihat peningkatan skor pengamatan skrining pada pemberian makan P0 pada awal pemberian makan periode pagisiang jam 07.00 dan awal pemberian makan periode sore-malam yaitu jam 15.00 dan setelah itu mengalami penurunan angka skor kembali. Hal ini disebabkan karena pada jam tersebut ayam mendapatkan pergantian pakan dengan pakan yang baru. Sehingga insting ayam akan lebih tertarik untuk mengonsumsi pakan yang baru dan segar.

\section{Pengaruh perlakuan terhadap jumlah patukan}

Rataan jumlah patukan ayam petelur jantan selama penelitian yang diberikan perbedaan persentase pemberian pakan dan pembatasan waktu makan, dapat dilihat pada Tabel 7.

Tabel 7. Rataan jumlah patukan ayam petelur jantan selama penelitian

\begin{tabular}{lc}
\hline \multicolumn{1}{c}{ Perlakuan } & Jumlah Patukan (Kali/5 Menit) \\
\hline P0 (adlibitum) & $2,54^{\mathrm{b}}$ \\
P1 (30\% pagi - siang 70\% sore - malam) & $2,99^{\mathrm{a}}$ \\
P2 (40\% pagi - siang 60\% sore - malam) & $2,96^{\mathrm{a}}$ \\
P3 (50\% pagi - siang 50\% sore - malam) & $2,88^{\mathrm{ac}}$ \\
P4 (60\% pagi - siang 40\% sore - malam) & $2,97^{\mathrm{ab}}$ \\
\hline
\end{tabular}

Keterangan: Superskrip dengan huruf berbeda pada kolom yang sama menunjukan berbeda sangat nyata $(\mathrm{P}<0,01)$.

Pengamatan dilakukan selama 5 menit pada saat ransum pertama kali diletakan, perhitungan dilakukan secara manual dengan hand counter dan rekaman video.

Berdasarkan hasil analisis ragam menunjukkan persentase jumlah pemberian pakan pada jadwal waktu pemberian makan memberikan pengaruh nyata $(\mathrm{P}<0,05)$ terhadap jumlah patukan ayam petelur jantan. Hal ini disebabkan oleh keinginan ayam untuk memenuhi kebutuhan energi yang hilang akibat tidak tersedianya pakan pada malam hari, sehingga pada pemberian pakan berikutnya ayam akan mengkonsumsi pakan untuk memenuhi kebutuhan energi terlebih dahulu (Rizal, 2000). Sesuai dengan pernyataan tidak ada indikasi ayam mampu mengantisipasi kapan ransum tidak tersedia, tetapi di hari berikutnya terjadi perubahan tingkah laku makan (feeding behaviour) karena ayam sudah terbiasa dilakukan secara terusmenerus dan berulang-ulang, maka ayam akan menjadi terbiasa sehingga menyebabkan jumlah patukan meningkat dan ayam dapat beradaptasi.

Seiring dengan yang dinyatakan oleh Andisuro (2011), produktivitas ayam broiler dapat diukur dari performa produksi seperti tingkat konsumsi pakan, konversi pakan, pertambahan bobot badan, dan bobot badan. Nilai produktivitas tersebut dapat diduga melalui tingkah laku yang terkait dengan hal tersebut. Tingkah laku hewan adalah suatu respon atau ekspresi hewan oleh adanya rangsangan yang memengaruhinya. Menurut Mukhtar (1986), rangsangan terbagi dua yaitu rangsangan luar dan rangsangan dalam. Rangsangan luar dapat berbentuk suara, pandangan, tenaga mekanis, dan rangsangan kimiawi. Rangsangan dalam antara lain adalah faktor fisiologis sekresi hormon dan faktor motivasi (Mukhtar, 1986). Menurut Prijono dan Handini (1998), tingkah laku juga dapat diartikan sebagai ekspresi seekor hewan yang dituangkan dalam bentuk gerakan-gerakan. Tingkah laku sekor hewan dipengaruhi oleh 
dua faktor, yaitu dari dalam (hormon dan sistem saraf) dan faktor dari luar (cahaya, suhu, dan kelembaban). Tingkah laku bersifat genetis, tetapi dapat berubah oleh lingkungan dan proses belajar hewan.

Dari hasil uji DMRT menunjukkan jumlah patukan $\mathrm{P} 1$ dan $\mathrm{P} 2$ berbeda sangatnyata $(\mathrm{P}<0,01)$ terhadap P0 (adlibitum). Perlakuan P3 berbeda nyata $(\mathrm{P}<0,05)$ terhadap $\mathrm{P} 0$ dan $\mathrm{P} 4$ berbeda tidak nyata $(\mathrm{P}>0,05)$ terhadap $\mathrm{P} 0$. Sedangkan P1, P2, P3 dan P4 menunjukkan berbeda tidak nyata $(\mathrm{P}>0,05)$. Hal ini menunjukkan tingkah laku makan yang dilihat dari jumlah patukan dipengaruhi oleh persentase jumlah pemberian pakan pada jadwal waktu pemberian makan.

Hasil penelitian ini menunjukkan ayam dengan persentase jumlah pemberian pakan yang lebih banyak pada pagi-siang (P1 dan P2) atau lebih banyak pada pemberian sore-malam (P3 dan P4) menunjukkan tidak berbeda nyata $(\mathrm{P}>0,05)$. Hal ini disebabkan karena ayam akan makan untuk memenuhi kebutuhan energi. Ayam yang cenderung makan dengan memilih pecahan jagung untuk dikonsumsi terlebih dahulu, karena jagung merupakan bahan ransum dengan karbohidrat yang tinggi, sehingga dengan mengkonsumsi jagung bisa memenuhi kebutuhan energi pada ayam dengan cepat. Sesuai dengan pernyataan Wahju (2004) energi yang dibutuhkan oleh ayam untuk pertumbuhan jaringan tubuh, produksi telur, menyelenggarakan keaktifan fisik dan mempertahankan temperatur tubuh yang normal, sumbernya berasal dari karbohidrat, lemak dan protein ransum.

Kelebihan jumlah patukan tidak memenuhi kebutuhan nutrisi ayam secara menyeluruh, karena ayam yang memilih pecahan jagung jadi cepat kenyang. Hal ini yang menyebabkan angka konsumsi ransum ayam yang diberikan perlakuan lebih rendah daripada ayam yang diberikan pakan adlibitum, karena ayam akan cepat kenyang pada awal pemberian makan akibat dari mengonsumsi jagung tersebut.

Penelitian ini menunjukkan kesempatan makan yang terbatas juga memengaruhi banyaknya jumlah patukan ayam pada pakan yang tersedia. Ayam yang diberikan pakan tanpa pembatasan waktu dan persentase pemberian memiliki kesempatan makan di malam hari, karena pada malam hari suhu cukup rendah dan menyebabkan ayam memiliki keinginan untuk mengonsumsi pakannya. Sesuai dengan pernyataan Andisuro (2011) bahwa pemberian cahaya secara terusmenerus selama 24 jam akan meningkatkan tingkah laku makan dan minum serta aktivitas lainnya. Seperti dilukiskan pada grafik Gambar 4.

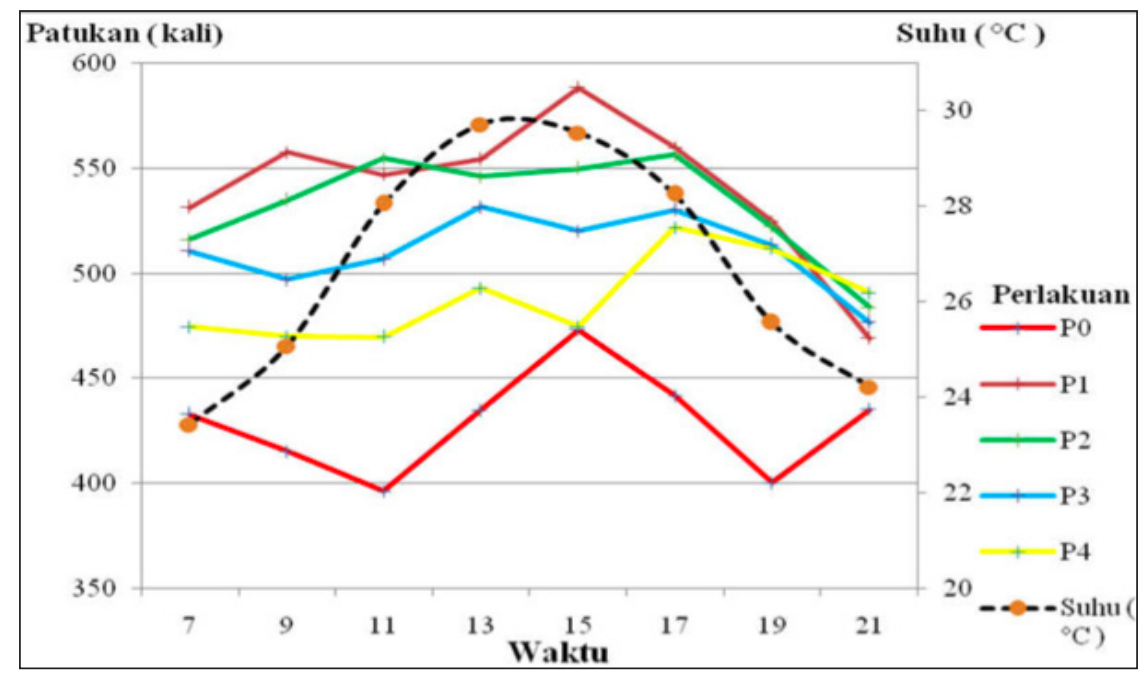

Gambar 4. Grafik jumlah patukan pada waktu pemberian pakan.

Berdasarkan Grafik di atas dapat dilihat jumlah patukan P1, P2, P3, dan P4 lebih banyak pada pemberian pakan pada waktu pagi-siang dan mengalami penurunan jumlah patukan pada pemberian pakan sore-malam. Hal ini disebabkan karena P1, P2, P3, dan P4 mengalami pemuasaan makan pada malam hari, sehingga ayam akan mengonsumsi pakan yang berlebih pada pemberian pakan berikutnya. Ayam yang diberikan pembatasan waktu makan pada malam hari menyebabkan temboloknya kosong sehingga meningkatkan konsumsi pakan pada pemberian pakan berikutnya. Setelah terpenuhi ayam tidak akan lagi memiliki keinginan mengkonsumsi pakan. Sesuai dengan pernyataan Rizal (2000) ternak 
dalam mengonsumsi ransum untuk memenuhi kebutuhan energi untuk hidup pokok, pertumbuhan, produksi dan reproduksi. Ketika energinya sudah terpenuhi maka ayam akan berhenti makan.

Pada perlakuan P0 yang diberikan kesempatan mengonsumsi pakan selama 24 jam lebih aktif makan pada awal pemberian makan dan pemberian makan malam hari. Awal pemberian makan P0 lebih aktif makan karena pergantian pakan sebelumnya dengan pakan baru yang lebih segar. Pada waktu pemberian makan malam hari terlihat P0 mengalami jumlah patukan yang meningkat. Hal ini disebabkan karena P0 selalu mendapatkan ketersediaan pakan dalam tempat pakan selama 24 jam. Sulistyoningsih (2004) menyatakan dalam keadaan suhu lingkungan yang panas hewan akan mengurangi kecepatan metabolisme dengan menurunkan konsumsi pakan. Penambahan panas dari hasil metabolisme menyebabkan hipotalamus merangsang kenyang. Temperatur lingkungan yang dingin menyebabkan kegiatan makan terus berlangsung sampai saluran pencernaan penuh sesuai dengan kapasitasnya.

Kusnadi (2009) menjelaskan kenyamanan akan merangsang pusat lapar yang berada di hipotalamus sementara pusat haus dihambat. Thyroid stimulating hormone (TSH) di hipotalamus juga ikut dirangsang sehingga kelenjer tiroid akan meningkatkan sekresi hormon tiroid baik triidotinonnin (T3) maupun tiroksin (T4). Hal ini akan meningkatkan konsumsi ransum dan pertambahan bobot badan.

Sistem faal untuk pengaturan feed intake sangat komplek, terdapat di hipotalamus dan bagian lain dalam sistem saraf pusat dan ada hubungan mekanisme "inhibitori" (pembatasan di pusat kenyang) terhadap respon makan. Daerah hipotalamus bagian lateral menjadi pusat kenyang dan di bagian ventromedial sebagai pusat lapar.

Pada perlakuan P4 memiliki jumlah patukan yang lebih sedikit pada pemberian makan pagi-siang, sedangkan pada pemberian makan sore-malam P4 memiliki jumlah patukan yang lebih banyak. Hal ini disebabkan kelebihan porsi pakan yang diberikan yaitu $60 \%$ pada pagi-siang yang menyebabkan ayam tidak terlalu memiliki keinginan mengonsumsi pakan karena kebutuhan hidup yang sudah terpenuhi dengan sangat cepat, sedangkan pada pemberian makan soremalam P4 mendapatkan porsi makan yang lebih sedikit yaitu $40 \%$. Suhu pada malam hari yang lebih rendah memungkinkan ayam untuk mengonsumsi pakan berlebih untuk meningkatkan kebutuhan energi. Temperatur lingkungan yang dingin menyebabkan kegiatan makan terus berlangsung sampai saluran pencernaan penuh sesuai dengan kapasitasnya (Sulistyoningsih, 2004).

\section{Pengaruh Perlakuan terhadap Jeda Makan}

Rataan hasil pengamatan waktu jeda makan ayam petelur jantan yang diberikan perlakuan persentase jumlah pemberian pakan dapat dilihat pada Tabel 8.

Pada Tabel 8 terlihat rataan waktu pengamatan jeda makan ayam petelur jantan P0 (235,64 detik), P1 (207,59 detik), P2 (220,53 detik), P3 (227,16 detik), dan P4 (216,79 detik). Hasil analisis ragam menunjukkan persentase jumlah pemberian pakan pada jadwal waktu pemberian makan tidak berpengaruh nyata $(\mathrm{P}>0,05)$ terhadap jeda makan ayam petelur jantan. Hal ini disebabkan ayam memforsir makan disaat awal-awal pemberian makan, sedangkan jeda makan diamati 30 menit setelah pemberian makan dilakukan dimana ayam tidak lagi menambah konsumsi pakan.

Tabel 8. Rataan waktu pengamatan jeda makan ayam petelur jantan selama penelitian

\begin{tabular}{lc}
\hline \multicolumn{1}{c}{ Perlakuan } & Jeda Makan (detik) \\
\hline P0 (adlibitum) & 235,64 \\
P1 (30\% pagi - siang 70\% sore - malam) & 207,59 \\
P2 (40\% pagi - siang 60\% sore - malam) & 220,53 \\
P3 (50\% pagi - siang 50\% sore - malam) & 227,16 \\
P4 (60\% pagi - siang 40\% sore - malam) & 216,79 \\
\hline
\end{tabular}

Keterangan: ns berbeda tidak nyata $(\mathrm{P}>0,05)$.

Pada penelitian ini jeda makan tidak dipengaruhi oleh jadwal waktu pemberian makan. Pada dasarnya ayam makan untuk memenuhi kebutuhan hidup pokok dengan mengonsumsi bahan pakan yang mengandung karbohidrat terlebih dahulu. 
Sesuai dengan pernyataan Wahju (2004) bahwa energi yang dibutuhkan oleh ayam untuk pertumbuhan jaringan tubuh, produksi telur, menyelenggarakan keaktifan fisik dan mempertahankan temperatur tubuh yang normal, sumbernya berasal dari karbohidrat, lemak dan protein ransum.

Hasil penelitian ini menunjukkan jeda makan ayam petelur jantan lebih lama dibandingkan ayam broiler. Hasil penelitian ini membuktikan broiler lebih aktif makan dibandingkan ayam petelur jantan.

\section{Pengaruh Perlakuan terhadap Sisa Pakan dalam Tempat Minum}

Rataan hasil penelitian sisa pakan dalam tempat minum ayam petelur jantan yang diberikan persentase jumlah pemberian pakan pada jadwal waktu makan dapat dilihat Tabel 9.

Tabel 9. Rataan sisa pakan dalam tempat minum ayam petelur jantan

\begin{tabular}{lc}
\hline \multicolumn{1}{c}{ Perlakuan } & Sisa pakan dalam tempat minum $(\mathrm{mg})$ \\
\hline P0 (adlibitum) & $8,32^{\mathrm{c}}$ \\
P1 (30\% pagi - siang 70\% sore - malam) & $11,5^{\mathrm{bc}}$ \\
P2 (40\% pagi - siang 60\% sore - malam) & $13,45^{\mathrm{abc}}$ \\
P3 (50\% pagi - siang 50\% sore - malam) & $17,78^{\mathrm{a}}$ \\
P4 (60\% pagi - siang 40\% sore - malam) & $14,47^{\mathrm{ab}}$ \\
\hline SE & 1,75 \\
\hline Keterangan : SE = Standar Error & \\
Superskrip dengan huruf yang berbeda pada kolom yang sama menunjukkan berbeda \\
sangat nyata (P<0,01).
\end{tabular}

Hasil analisis sidik ragam menunjukan persentase jumlah pemberian pakan pada jadwal waktu pemberian pakan berpengaruh nyata $(\mathrm{P}<0,05)$ terhadap sisa pakan dalam tempat minum. Hal ini disebabkan ayam yang diberikan perlakuan persentase jumlah pemberian pakan pada jadwal waktu makan mengonsumsi pakannya lebih cepat dan terburu-buru untuk memenuhi kebutuhan energi yang hilang pada saat makan yang dibatasi malam hari. Berbeda dengan ayam yang diberikan pakan adlibitum (P0) yang mendapatkan kesempatan makan di malam hari sehingga tidak terburu-buru dalam mengkonsumsi pakan dan tidak banyak pakan terbuang pada tempat minum.

Uji Duncan Multiple Range Test (DMRT) menunjukkan perlakuan P3 berbeda sangat nyata $(\mathrm{P}<0,01)$ terhadap $\mathrm{P} 0$, tetapi berbeda nyata $(\mathrm{P}<0,05)$ terhadap $\mathrm{P} 1$. Perlakuan $\mathrm{P} 4$ berbeda nyata $(\mathrm{P}<0,05)$ terhadap $\mathrm{P} 0$ dan tidak menunjukkan perbedaan nyata $(\mathrm{P}>0,05)$ terhadap P1, P2, dan P3. Sedangkan P2 tidak mengalami perbedaan nyata $(\mathrm{P}>0,05)$ terhadap semua perlakuan.

Hal ini disebabkan oleh salah satu faktor yang memengaruhi yaitu tingkat keterburuan dalam mematuk pakan. Ayam yang memiliki tingkat keterburuan konsumsi pakan yang tinggi dapat menimbulkan banyaknya sisa pakan yang tumpah dan menempel pada paruh. Selanjutnya dijelaskan oleh Muklis (2003) ayam pedaging minum dengan cara mencelupkan paruhnya ke dalam tempat minum lalu menelan air minum dengan cara mengangkat kepalanya ke atas, dan dilakukan sebanyak 3-5 kali. Tingkah laku minum dilakukan untuk menjaga keseimbangan air dalam tubuh karena meningkatnya suhu lingkungan dan untuk membantu dalam pencernaan pakan. Sulistyoningsih (2004) menyatakan konsumsi minum dipengaruhi oleh lama tingkah laku minum, mencari air, memasukkan air ke mulut dan menelannya. Tingginya konsumsi air erat kaitannya dengan mekanisme pendinginan. Ditambahkan oleh Rasyaf (1993) kebutuhan jumlah air minum broiler dipengaruhi oleh suhu, kelembaban udara dan bentuk fisik pakan. Pada suhu panas umumnya DOC akan banyak mengonsumsi air minum, hal ini bertujuan untuk menurunkan suhu tubuh dan sekaligus sebagai pelepas dahaga. Pada awal dimasukkan ke dalam kandang yang harus diberikan dan diperkenalkan pertama kali pada DOC adalah air minum. Air minum ini dicampur dengan gula dan diberikan pada dua jam pertama agar tenaga dan stamina DOC kembali pulih (Fadillah, 2004).

\section{KESIMPULAN}

Ayam petelur jantan yang diberikan pakan adlibitum menunjukkan tingkah laku makan lebih tenang dari ayam yang diberikan makan 
dengan persentase dan jadwal waktu makan. Manajemen persentase jumlah pemberian pakan dengan jadwal waktu pemberian mempengaruhi tingkah laku makan ayam petelur jantan.

\section{DAFTAR PUSTAKA}

Andisuro, R. 2011. Tingkah laku ayam broiler di kandang tertutup dengan suhu dan warna cahaya berbeda. Skripsi. Departemen Ilmu Produksi dan Teknologi Peternakan. Fakultas Peternakan. Institut Pertanian Bogor. Bogor.

Batubara, L. 2012. Pengaruh penggunaan jamur tiram (Pleuoretus ostreatus) dalam ransum terhadap total kolestrol, HDL, LDL plasma darah ayam broiler. Skripsi. Fakultas Peternakan Universitas Andalas, Padang.

Charles, D. R. 2002. Responses to the thermal environment. In Environment Problem, A guide to solution (Charles, D.A. and Walker, A.W. Eds.), Nottingham, United Kingdom, pp $1-16$.

De jong, I. C., A. S. Van Voorst, \& H. J. Blokhuis. 2003. Parameters for quantification of hunger in broiler breeders. Physiol. Behav. 78:773-783.

Fadilah. 2004. Panduan Mengelola Peternakan Ayam Broiler Komersial. Agromedia Pustaka. Jakarta.

Jahja, 2000. Ayam Sehat Ayam Produktif. Petunjukpetunjuk Beternak Ayam. Edisi ke-18. Medion Press, Bandung.

Jerry. 2005. Tingkah laku harian dan tingkah laku makan ular sanca hijau di CV Terarria Indonesia. Skripsi. Fakultas Peternakan Institut Pertanian Bogor. Bogor.

Kusnadi, E. 2009. Perubahan Malonaldehida Hati, Bobot Relatif Bursa Fabricius dan Ayam Broiler. Agromedia Pustaka, Jakarta.

Laboratorium Teknologi Industri Ternak. 2016. Fakultas Peternakan. Universitas Andalas.
Nuraini, M. E. Mahata, \& Nirwansyah. 2013. Response of broiler feed cocoa pod fermented by Phanerocaete chysosporium and Monascus Pupureus in the diet. Pakistan Journal of Nutrition 12. (9): 886-888.

Muchtar, A. S. 1986. Dasar-dasar Ilmu Tingkah Laku Satwa (Ethologi). Direktorat Jenderal Perlindungan Hutan dan Pelestarian Alam. Departemen Kehutanan, Bogor.

Muklis. 2003. Aktivitas yang berhubungan dengan perilaku makan kukang Sumatra (coucang coucang) di penangkaran pada malam hari. Skripsi Fakultas Peternakan Institut Pertanian Bogor. Bogor.

Prijono, S. N. \& S. Handini. 1998. Memelihara, Menangkar dan Melatih Nuri. Penebar Swadaya. Jakarta.

Rasyaf. 1993. Beternak Ayam Pedaging. Penebar Swadaya. Jakarta.

Rizal, Y. 2000. Respon Ayam Broiler terhadap Pengganti Bungkol Kedelai dengan BIS Dalam Ransum. Jurnal Peternakan dan Lingkungan Volume 6 Issue 02.

Sulistyoningsih, M. 2004. Respon fisiologis dan tingkah laku ayam broiler periode starter akibat cekaman temperatur dan awal pemberian pakan yang berbeda. Tesis. Universitas Diponegoro. Semarang.

Wasiudin, A.A., 2011. Strategi pengembangan usaha ayam petelur jantan pada UD Mengestoni Putri Poultry Shop di Desa Gading Sari Kecamatan Sandeng Kabupaten Bantul. Sikripsi. Departemen Agribisnis Fakultas Ekonomi dan Manajemen Institut Pertanian Bogor, Bogor.

Wahju, J. 2004. Ilmu Nutrisi Unggas. Cetakan ke-V. Gadjah Mada University Press. Yogyakarta.

Widya Karya Nasional Pangan dan Gizi. 2012. Prinsip dasar Ilmu Gizi. Jakarta : PT Gramedia Pustaka Utama. 